RADEK MalÝ

Univerzita Karlova

\title{
The Figure of Ophelia in Expressionist Poetry: German and Czech Comparison
}

\section{Introduction}

There are motifs in art history that represent such an integral part of a certain art movement or epoch that they co-define it. Since antiquity, European culture has known the motif of a beautiful drowned young woman. Having been transformed throughout centuries, this motif has fulfilled various functions based on the period aesthetic canon and the general cultural perception of women and womanhood. ${ }^{1}$ The nineteenth century saw a major escalation of the motif of the drowned beauty ${ }^{2}$ and its substantial re-interpretation in connection with the arrival of modern art movements. It could even be seen as a cult of the young drowned woman which found one of its climaxes in German Expressionist poetry in the early twentieth century. Another possible peak of the use of this motif can be seen in the frequency and diversity of the appearance of the figure of the "Unknown Woman of the Seine" (L'Inconnue de la Seine in French) in literature (including the Czech one). ${ }^{3}$

1 For more detail, see Bronfen 2004.

2 This would be the English equivalent of the German term "schöne Wasserleiche."

3 A young woman who drowned in the Seine in the late 1880s, who has not been identified to this day and whose death mask inspired many twentieth-century artworks. For more detail, see Malý 2007. 
In the context of European art, the motif of the drowned beauty was rediscovered by Symbolism, including the artistic rendering of the character of Ophelia from William Shakespeare's drama Hamlet. In the play, Ophelia is a young woman who loses her sanity after her beloved Hamlet, who rejects her, unknowingly kills her father. She then drowns, rather by mischance than of her own will. Her figure became a clear projection of the motif outlined above. ${ }^{4}$ Symbolist painters reveled in the figure of drowned Ophelia. While early on, it was rendered rather as an illustration to Shakespeare's drama, later the motif emancipated itself into images with a broad range of possible interpretations, with the most renowned visual renditions including Ophelia by British Pre-Raphaelite John Everett Millais from 1891 and Ophelia by Czech painter Jan Konůpek from 1906. ${ }^{5}$

In the field of literature, one of the renditions that is most remarkable for its modern and initiatory character is the poem "Ophélie" (Ophelia) written in 1870 by Jean Arthur Rimbaud. With its nine four-verse stanzas, the poem is a typical representative of Rimbaud's early stage (it even has a textual precursor in Latin) written in a strict metrical form in the spirit of Symbolism. Some researchers even point out that the poem is partially derived from some of the poems written by Parnassianist Théodore de Banville (1823-1891), a conventional romanticizing poet, who is considered the discoverer of Rimbaud's talent (Bayer 218).

Nevertheless, the poem shows clear signs of Rimbaud's idiosyncratic style: it develops motifs of the aesthetics of ugliness, known since Charles Baudelaire, while other symptomatic aspects include a radical use of the poetic image leaning towards an absolute metaphor, and a striking, often surreal colourfulness transcending to synaesthesia. While the poem contains elements from the play Hamlet (the name of the female figure in the poem's title, an allusion to a "handsome pale knight" - i.e. Hamlet-in the seventh stanza, some scenery, and the mention of the "great mountains of Norway" in the fifth stanza), the figure of Ophelia is rid of all other individual features. In the first stanza, the figure is embedded in the setting of idyllic nature, with the comparison to a white lily reappearing in the last stanza and thus constituting a certain

4 In his study L'Eau et les rêves. Essai sur l'imagination de la matière published in 1942, French philosopher Gaston Bachelard describes water as an exclusively melancholic element related exclusively to female death and coins the term of the "Ophelia complex" in this context.

5 The rendition of the biblical figure of Salome received similar attention; however, unlike the dead, and thus "harmless" Ophelia, Salome represents the prototype of dangerous female seductiveness. 
framework of the poem. The second stanza relocates the figure into a certain mythical timelessness. In the second part of the poem, Ophelia is addressed by the poetic subject that becomes the object of the poem in the last stanza which constitutes the separate third part of the poem. Let me quote the first two stanzas and the last stanza from the original poem: ${ }^{6}$

Sur londe calme et noire où dorment les étoiles La blanche Ophélia flotte comme un grand lys, Flotte très lentement, couchée en ses longs voiles ...

-- On entend dans les bois lointains des hallalis.

Voici plus de mille ans que la triste Ophélie

Passe, fantôme blanc, sur le long fleuve noir;

Voici plus de mille ans que sa douce folie

Murmure sa romance à la brise du soir.

-- Et le poète dit qu'aux rayons des étoiles

Tu viens chercher, la nuit, les fleurs que tu cueillis,

Et qu'il a vu sur l'eau, couchée en ses longs voiles,

La blanche Ophélia flotter, comme un grand lys. (Rimbaud 188)

In English translation:

On the calm black water where the stars are sleeping

White Ophelia floats like a great lily;

Floats very slowly, lying in her long veils ...

- In the far-off woods you can hear them sound the mort.

For more than a thousand years sad Ophelia

Has passed, a white phantom, down the long black river.

For more than a thousand years her sweet madness

Has murmured its ballad to the evening breeze.

- And the poet says that by starlight

You come seeking, in the night, the flowers that you picked

And that he has seen on the water, lying in her long veils

White Ophelia floating, like a great lily. (Rimbaud, Poetry Nook)

6 Due to the extensive length of most of the poems discussed, only excerpts from the original versions and their English translations will be stated here. 
Rimbaud's Ophelia is a dreaming visionary, one that is similar to Rimbaud's description of the poet and his newly defined poetics in the renowned "letters of the seer." However, the burden of this utopian vision kills the figure; she does not have the power to carry it. She becomes a general type of a beautiful drowned young woman who is at the same time the poet's muse in between worlds; she is the connection between our world and the other world. She is worth the poet's attention for she escapes the ever less graspable reality in two ways: by insanity and by death.

However, returning back to reality from this journey is impossible, and so is rendering it in words. The contrast between Ophelia's silence and its poetic reflection is voiced in the first verse of the third part, i.e. in the last stanza: Et le poète dit (And the poet speaks (says)). As if Rimbaud alluded to his later silence: at the age of nineteen, the poet fell silent in a way that represents an essential gesture of modern poetry from today's perspective. Here already, he anticipates the deep crisis of modern poetry as later formulated by Hugo von Hofmannsthal in his famous fictional Brief des Lord Chandos (The Letter of Lord Chandos) due to his scepticism concerning the possibility of capturing the world through the language of poetry.

\section{German Expressionism}

Rimbaud's poem "Ophelia" as well as the perception of his complete work and life had a significant impact on the poetry of German Expressionism. What was in the beginning of this relationship was the German translation of Rimbaud's poems by Karl Klammer (1879-1959), a Vienna native who was a colonel of the Austrian army in his civilian life. The key year of 1907 saw the publication entitled Arthur Rimbaud. Leben und Dichtung (Arthur Rimbaud. Life and Work), an anthology of the work of Arthur Rimbaud including approximately a half of his works and prefaced by an extensive biographical study by Stefan Zweig. The book was published under the translator's transparent pseudonym K.L. Ammer.

Through his distinctive Rimbaud translations, K.L. Ammer initiated a remarkable offshoot of the entire literary epoch — that of German Expressionism. This offshoot drew on Symbolism, which was practically reduced to the specific work of Stefan George and Rainer Maria Rilke in the field of German poetry, as well as on the sentiments stemming from the Decadents. Klammer's book of Arthur Rimbaud's translations gave rise to the poetics of several German poets. Three of them, previously often perceived as pre-Expressionists by literary history, are now rightly interpreted as fundamental figures of modern German poetry: Germans Georg Heym and Gottfried Benn and Austrian Georg Trakl. 
For all three, the turning point in the formation or transformation of their poetics came approximately in the year 1910, which is now seen as the beginning of the Expressionist decade. All three of them, yet not only them, addressed the motif of a drowned young woman in their work in some way.

Especially to Georg Heym (1887-1912), a poet of the turbulently developing city of Berlin, water was a fundamental element, often appearing as the cool, eternal, clear blue in his poetry. The influence of Rimbaud's "Ophelia" is most distinct in Georg Heym's work, assuming very particular features. Heym addressed this topic in two of his longer poems from 1910, Tote im Wasser (The Dead Girl in the Water) and Ophelie (Ophelia). Heym's "Ophelia" is one of the first treatments of the motif that is based secondarily on Rimbaud's poem rather than Shakespeare's drama. The twelve-stanza composition was written in October 2010 and shows all the key features of Heym's mature poetic style: contrary to the broken form, which is otherwise very common in Expressionism, it is written in a strict metrical form with iambic metre and enclosed rhyme (alternate rhyme in two stanzas), consisting of two parts of different length (four and eight stanzas).

Unlike Rimbaud's text, Heym's “Ophelia” underwent the experience of the Decadence on which Expressionism partly draws to paradoxically imbue it with new life; in Expressionism, the aesthetics of ugliness is taken to the extreme, as shown by Gottfried Benn (see below). The motif of death is intensified and the passages capturing the transition from beauty to ugliness are accentuated. What is characteristic in this respect is the contrast between the title, raising certain expectations and the first verse which goes: "Im Haar ein Nest von jungen Wasserratten" (In Her Hair a Nest of Young Water Rats). This unexpected sharp cut is so intense that the following stanzas, rather static and descriptive, still carry on in the spirit of its imagery and paradoxical vitality. While in Rimbaud's "Ophelia," the nest resounds with the flapping of birds' wings, in Heym's "Ophelia," water rats live in Ophelia's hair. While the bosom of Rimbaud's Ophelia is kissed by the wind, a long white eel creeps across the breast of Heym's Ophelia. Remarkably, the space of the poem is brought to life by many particular animals (rats, eel, a firefly, bats, swans) and plants (jungles, fern, reeds, willow, rye). As if these living organisms were to create a counterbalance to the expectable process decomposition, pointing out the new life of the dead body. This process of animalization corresponds with the fact that the name of Ophelia only appears in the title of Heym's poem, while in Rimbaud's poem, Ophelia is also addressed in the text.

In the second part, the ductus of the poem changes significantly. The dynamic character is reinforced, especially by accentuating the movement down 
the river and the repetition of the adverb vorbei, vorbei (passing, passing) at the beginning of the seventh and eleventh stanza. Moreover, there is a typical Heymian scenery of a demonically anthropomorphized metropolis from which Ophelia is moving away: the cry of machines and primarily a giant crane completely dominating the ninth stanza:

Mit schwarzer Stirn, ein mächtiger Tyrann,

Ein Moloch, drum die schwarzen Knechte knien.

Last schwerer Brücken, die darüber ziehn

Wie Ketten auf dem Strom, und harter Bann. (Heym 161)

in English translation:

A mighty tyrant, black, perverse,

A moloch worshipped by his dour knaves.

The weight of bridges resting on the waves

Like heavy chains, and everlasting curse. (Heym, Steinmann)

Heym's Ophelia, put in a completely contemporary setting, distances herself from the city not only in space but also in time: for the adverb "vorbei" encompasses the temporal meaning as well. This temporal tendency towards eternity, to Rimbaudian "timelessness," dominates the final stanza with an apocalyptic tone:

Der Strom trägt weit sie fort, die untertaucht,

Durch manchen Winters trauervollen Port.

Die Zeit hinab. Durch Ewigkeiten fort,

Davon der Horizont wie Feuer raucht. (Heym 162)

In English translation:

The waters carry her, as she sinks down,

Through mournful ports of many winter nights.

Through time, and through eternity, that lights

The vast horizon like a burning crown. (Heym, Steinmann)

What is also remarkable is a certain sacralization of the space inhabited by Ophelia: the second stanza includes the noun "Schrein" (a shrine), the twelfth stanza includes the verb "weihen" (to consecrate, sacred day). This corresponds 
to the earlier depictions of the drowned young woman in fine arts where she is portrayed as Mary or as a saint.

Georg Trakl (1887-1914) is traditionally labelled as Heym's Austrian contemporary and lyrical doppelganger. However, if we take a closer look at this poet, who is traditionally acclaimed as a distinctive representative of Expressionism with an original poetic spirit who significantly influenced Austrian as well as Czech poetry, we will be surprised to find out that Klammer's translations of Rimbaud's poems not only initiate the originality of Trakl's talent but even enter brand new, unexpected contexts through dozens of literal as well as loose quotations within Trakl's poetic work, thus taking further effect. It is only due to Trakl's poetic genius that he managed to transform the influence of other poets on his poetry into a unique synthesis of original interpretations of derived inspirations - which were in no way hidden by the poet yet unsuspected by his contemporary readers-thus introducing the denial of the traditional requirement of poetic originality into modern poetry for the first time in such a compact form, while relativizing this requirement to the maximum degree possible.

Rimbaud's influence on Trakl was noted already in 1925, i.e. rather soon, by Adolf Meschendörfer, who found primarily literal quotations from Klammer's translations in Georg Trakl's work; the list is exhaustive (Menschendörfer 93). The deeper connections between Rimbaud and Trakl, or rather Klammer's Rimbaud translations and Trakl, were noticed by Reinhold Grimm, who was also the first to point out the significance of Klammer's translations in German poetry (Grimm 1959: 288-315 and Grimm 1982: 124-145). Ophelia even makes a fleeting appearance in Georg Trakl's poetry-in the first version of the poem "Wind, weiße Stimme ..." (Wind, white voice ...) which was probably written in late 1912 and remained unpublished during Trakl's lifetime. Let me quote the first stanza and the poem's ending.

Wind, weiße Stimme, die an des Schläfers Schläfe flüstert In morschem Geäst hockt das Dunkle in seinem purpurnen Haar Lange Abendglocke, versunken im Schlamm des Teichs Und darüber neigen sich die gelben Blumen des Sommers. Konzert von Hummeln und blauen Fliegen in Wildgras und [Einsamkeit,

Wo mit rührenden Schritten ehdem Ophelia ging Sanftes Gehaben des Wahnsinns. Ängstlich wogt das Grün im Rohr Und die gelben Blätter der Wasserrosen, zerfällt ein Aas in heißen 
Erwachend umflattern den Schläfer kindliche Sonnenblumen.

O Tod! Der kranken Seele verfallener Bogen Schweigen und [Kindheit.

Aufflattern mit irren Gesichtern die Fledermäuse. (Trakl 180)

In English translation:

Wind, white voice that whispers near the temple of the sleeper In rotten branches the darkness crouches in his purple hair Long evening bell, sunk in the mud of the pond And over it the yellow flowers of the summer bend.

Concert of bumblebees and blue flies in wild grass and loneliness, Where once Ophelia went with stirring steps

Soft behavior of insanity. Anxiously the green surges in the reeds And the yellow leaves of the water lilies, a carcass molders in hot [nettles

Awaking childish sunflowers flutter around the sleeper.

O death! The ill soul's decayed arch silence and childhood.

With mad faces the bats flutter up. (Trakl, Literaturnische)

The poem, written in free verse, anticipates the later stage of Trakl's work and is characteristic in many respects: the verses are arranged without any significant syntactic connections, making the impression of isolated images; while these images are mostly known from Trakl's other texts, the only thing that changes is the context into which they are embedded. The separation of the last verse into an individual stanza is typical as well.

Images of idyllic nature abounding in summer flowers and buzzing insects are disturbed by negative visions of darkness in rotten branches (verse two), a carcass (verse eight) and finally an ill soul and death (verse seventeen). These images of destruction and decay are associated with the figure of Ophelia who is again connoted with the phrase of "soft madness" analysed above. In Trakl's poems, too, Ophelia constitutes a link-though its contours are rather blurredbetween our world and the "other" world, rather than a mere representation of a literary figure. However, remarkably, Ophelia does not appear in the second preserved version of this poem.

The most radical treatment of the theme of a drowned young woman (though she is not named Ophelia) can be found in the poetry of Berlin poet 
(and doctor) Gottfried Benn (1886-1956). His literary debut, a notebook with nine poems entitled Morgue und andere Gedichte (Morgue and Other Poems) ${ }^{7}$ was published in March 1912, two months after Heym's drowning, in Berlin in 500 copies. Against the author's will, this thin collection caused a literary and social scandal, securing him a leading position among the Expressionists. Gottfried Benn recollects the circumstances of the origin of this cycle in his memoir Lebensweg eines Intellektualisten (The Way of an Intellectualist) from 1934:

Als ich "Morgue" schrieb, mit der ich begann und die später in so viele Sprachen übersetzt wurde, war es abends, ich wohnte im Nordwesten von Berlin und hatte im Moabiter Krankenhaus einen Sektionskurs gehabt. Es war ein Zyklus von sechs Gedichten, die alle in der gleichen Stunde aufstiegen, sich herauswarfen, da waren, vorher war nichts von ihnen da; als der Dämmerzustand endete, war ich leer, hungernd, taumelnd und stieg schwierig hervor aus dem großen Verfall. (Benn IV: 177)

When I wrote "Morgue," with which I began and which was later translated into so many languages, it was evening, I was living in the northwest of Berlin and attending a dissection course at Moabit Hospital. It was a cycle of six poems, which all came to me in the same hour, flung themselves up from below, where previously nothing had been. When my semiconscious state ended, I was empty, hungry, dizzy and climbed with difficulty out of the great decay. (Huyssen 84-117)

The Morgue ${ }^{8}$ cycle includes a brief poem entitled "Schöne Jugend" (Beautiful Youth):

Der Mund eines Mädchens, das lange im Schilf gelegen hatte sah so angeknabbert aus.

Als man die Brust aufbrach war die Speiseröhre so löcherig.

Schließlich, in einer Laube unter dem Zwerchfell

7 The inspiring character of this morbid theme is proved by the fact that Georg Heym and Rainer Maria Rilke each wrote a poem with an identical title in the same time period.

8 The term originally designated the Paris morgue which displayed dead bodies for the purpose of their identification. Later on, the term was broadened to similar institutions in other big cities including Berlin. 
fand man ein Nest von jungen Ratten.

Ein kleines Schwesterchen lag tot.

Die anderen lebten von Leber und Niere,

tranken das kalte Blut und hatten

hier eine schöne Jugend verlebt.

Und schön und schnell kam auch ihr Tod:

Man warf sie allesamt ins Wasser.

Ach, wie die kleinen Schnauzen quietschen! (Benn I: 24)

The mouth of the girl who had lain long in the rushes

looked so nibbled.

When they opened her chest, her esophagus was so holey.

Finally in a bower under the diaphragm

they found a nest of young rats.

One little thing lay dead.

The others were living off kidneys and liver

drinking the cold blood and had

had themselves a beautiful youth.

And just as beautiful and quick was their death:

the lot of them were thrown into the water.

Ah, will you hearken at the little muzzles' oinks! (Benn, Hofmann)

In the context of the author's biography, it is obvious that Benn was familiar with the figure of a drowned young woman in the particular form of a common working day rather than a literary symbol of its time. However, already in the 1950s, researcher Bernhard Blume termed this poem as a "waste product of Rimbaud's Ophelia" (Blume 113); interestingly though, Gottfried Benn claims to only have delved into Rimbaud's poetry much later. ${ }^{9}$ Nevertheless, leaving aside the pioneering matter-of-factness, which is still shocking today, and the thorough treatment of the topic in its macabreness, one can find very convincing links between this poem and the poetic style of Heym and Trakl. Benn's poem, too, addresses the general Expressionist theme of decay, and similarly to Heym's poem, it portrays the drowned young woman as disfigured by water rats. However, the depiction is substantially different from the one of Heym, as Benn's poem dehumanizes the figure of the drowned young woman, depriving it of all aesthetic features and turning it into a vessel in which water rats survive.

9 This was Benn's sceptical response to the attempts of literary historians to categorize his poem as one of the poems directly inspired by Rimbaud's "Ophelia" (Benn IV: 380 ). 
Benn commits a total destruction of what is traditionally perceived as aesthetic. This is one of the reasons to be cautious when considering an ironical reading, which would only ridicule something that is, something that exists. While the effect of shocking the bourgeois cannot be denied (this aspect is generally strong especially in early Berlin Expressionism), what is more prominent here is an extreme reaction of the lyrical subject to the complete disillusion of the modern world which cannot be comprehended and grasped by words.

\section{Expressive Depiction of the Drowned Young Woman in Czech Poetry}

Czech poetry, too, abounds in powerful images that are inspired by the vision of the tragic death of a beautiful young woman in connection with the water element; there is a whole range of such texts. However, we will focus on how this motif is represented in selected poems whose expression is the closest to the intensity of depiction in German Expressionism.

In Czech poetry, this motif is most often treated as a balladic narrative of women who commit suicide with various motivations for their act, which already appeared in Czech and Moravian folklore. This is also the case with one of the most renowned poems by Petr Bezruč (1867-1958) - the ballad Maryčka Magdónova (Marycka Magdonova). The expressive depiction of Marycka's suicide in the mountain creek explicitly mentions the girl's hair, although this time it is not floating on the surface but caught on the rocks:

Maryčko, po straně ostré jsou skály, podle nich kypí a utíká k Frydku šumivá, divoká Ostravice.

Slyšíš ji, rozumíš, děvucho z hor?

Jeden skok nalevo, po všem je, po všem.

Černé tvé vlasy se na skále chytly,

bílé tvé ruce se zbarvily krví,

sbohem bud', Maryčko Magdónova! (Bezruč 74)

In English translation:

Steep, Marycka, steep the rocks rise

Where the Ostravice wild and foaming

hurls its torrents down to Frýdek.

Do you hear, do you see, lass of the hills? 
One leap to the left and all is over.

Your black hair caught on the rocks below.

red with blood are your white hands,

God be with you, Marycka Magdonova! (Bezruč, Milner)

In the epic line of the poetry of Vladimír Holan (1905-1980), there is a passage which, without explicitly mentioning Ophelia as a literary figure, precisely represents the Ophelia complex as defined by Bachelard. The passage comes from the poem Návrat (Homecoming) first published in 1948:

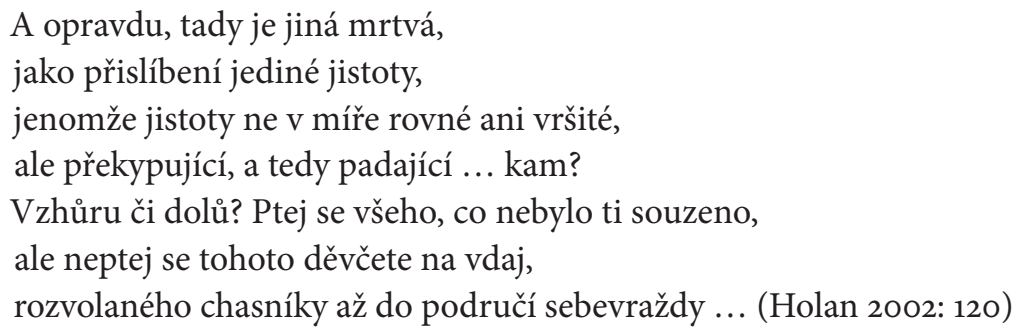

In English translation:

And indeed, here is a different dead woman:

like the promise of a single certainty, a certainty not limited to a level or to a stacked measure, but one that is abundant and therefore descending ... Whereto? Upward or downward? Question everything that hasn't been [adjudged to you, but don't ask anything of this marriageable girl who'd been deranged by country lads as far as suicide's servitude ...

(Holan, Narrative Poems)

The micro story of a figure named Anežka is one of three suicide stories in the cycle. The young woman goes insane as a result of the interest of her suitors and chooses voluntary death in the water element. Thus, the figure directly corresponds to Gaston Bachelard's characteristic of the Ophelia complex: "Water is the element of young and beautiful death, of flowery death, and in the dramas both of life and literature, the element of a death with neither pride nor vengeance-of masochistic suicide" (Bachelard 108).

It is perhaps due to this connection to a cultural archetype, enabling its general validity, that Anežka's tragedy makes the most intensive impression on 
the readers out of all the three suicide stories in Homecoming. Holan's allusion to the motif of a beautiful drowned woman meets the balladic element known from folklore, forming a massive stream of associations linked to tragic female death. In Vladimír Holan's poetry, the motivic affinity to Bachelard's Ophelia complex, combined with the folklore tradition, contributes to the constitution of the broader meaning of the poem, confirming the essence of the archetype consisting in its position beyond individual consciousness.

Holan's work from the second half of the 1940s includes a poem whose expressivity and systematically employed aesthetics of ugliness can compete both with French Decadents and German Expressionists:

\section{But Never Doubt I Love}

Vodní krysa u prsu utonulé Ofélie, rozželená jeho modřinou a předpletovou vůní, kničivě soptí, vzdychá, podupává, mluví nosem a spouští tklivá včichnutí po kulovitých zkratkách slin do kručení žárlivého na proud řeky, když náhle spatří na břiše utopenky masařku. Ihned tam přebíhá a začíná trhat jeho potuchlou, snadno se vzdávající kůži, hryže a rve a saje, kousá, loupí a polyká, ochutnává ponorné průvany, drásá a vyškubává jemnější zakřriknuté žíly, prohlodává se kř́ižem krážem a zapíjí to crkavě $\mathrm{z}$ tůněk, které tam zatajily stonavé cáry, krhavé vrapy a drzé mraky mázder a blan, zárících jako její mlaskání, cpe maso zpředu do všech konců vědomí a celá houstne a těžkne při svém vysedlém olysání ...

Ale jak uraženě znedůvěří

a číhavě zasklívá své levé oko, když se jí v tom rozryvném vyšklebení života ukáže dětské tílko ... (Holan 2000: 102)

In English translation: 
A water rat, at the breast of drowned Ophelia, grieving over the bruises and the scent void of any complexion, squeals, sighs, kicks up its heels, talks through its nose, and drops down its touching snuffles along the globular acronyms of spit to its rumble, jealous of the stream of the river, when, suddenly, it sees a bluebottle at the belly of the drowned.

Immediately, it runs there, and begins to tear the musty skin, which gives up easily; it gnaws and tears and sucks; it bites, robs and gobbles; it tastes the submersible draughts; it mauls and plucks up some finer sheepish veins; it eats through, criss-cross, and, dribbling, it rinses down from little pools concealed there by sickly rags, scrubby wraps and shameless clouds of tissues and membranes, aglow as its smacking;

it crams the flesh from the front into all the ends of consciousness, and it thickens all around and turns heavy in its bulbous baldness ...

But, look, how it turns offensively distrustful, and, watchful, glazes its left eye, as, in that dissected maw of life, a little body of a baby appears ... (Holan, Yet There Is Music)

The poem "But Never Doubt I Love" was only published in book form in Holan's poetry collection $\mathrm{Na}$ postupu (On the Advance) in 1964; however, prior to that, it had been published in magazine form in the second edition of the Blok revue in early 1947; which rather modifies the observation made by literary critic and Holan's editor Michael Špirit who claimed that Holan was only strongly fascinated by Shakespeare later (Špirit 153). The poem's title is a quotation from Shakespeare's Hamlet; in particular, of the fourth verse from the rhymed poem in Hamlet's letter to Ophelia in which he declares his love for her and which is read by Polonius to Gertrude: 


\author{
Doubt thou the stars are fire, \\ Doubt that the sun doth move, \\ Doubt truth to be a liar, \\ But never doubt I love. (Shakespeare 74)
}

In his study examining multilinguality in Vladimír Holan's poetry, Petr Mareš formulates a thesis concerning this poem, which I can only agree with, saying that by using this element, Holan evokes the figure of Ophelia, who is the theme of the poem, on the one hand, while "creating an ironic contrast between an excerpt from Hamlet's love letter and the drastic images of a dead body" (Färber 2006: 121) on the other hand. The graphic images in the depiction of a dead body will undoubtedly stir an essential impression in the readers. They are images of an intense, expressive poetic based on an almost baroque ornamentality and evocation of contradictions as well as on the aesthetic of ugliness in which German Expressionism reveled.

These two connections were also noticed by Italian Bohemist Mario Ripellino (1923-1978), who translated Holan's poetry and who mentioned "But Never Doubt I Love" in his introduction to the collection of Vladimír Holan's poetry in Italian: "In Holan's work, the Baroque often merges with the stylistic methods of Expressionism.... The lyrical poem "But Never Doubt I Love," with its repulsive description of a rat gnawing and tearing at the skin of drowned Ophelia, is close to two compositions by German Expressionists: Georg Heym's "Ophelia," where the drowned woman has "a nest of young rats in her hair," and the poem Schöne Jugend where Gottfried Benn describes how a dissection reveals a nest of "young mice" feeding on the girl's liver and kidneys" (Ripellino 1968: 33).

Holan himself was rather sceptical about looking for connections between his work and European poetry, as proved by his ironic remark in an interview with Jaroslav Deweter from 1959: "Italian Slavist A.M. Ripellino, who once translated some of my handwritten poems, dedicated a very interesting study to me, according to which my poetry was influenced by two authors: Khlebnikov and Elizabethan poet John Donne. What a pity that I don't speak English. I believe that looking for influences is always very problematic" (Holan 2006: 501). However, the affinity between his poem and the poetics of early Expressionists is surprising and requires a more detailed insight than that of Ripellino's fleeting observation.

The degree of alienation is absolute both in the case of Holan and Benn: the anonymous drowned young woman has nothing in common with Ophelia 
as the poet's muse. Any transcendence is brutally negated and the boundary between the outside world and the lyrical subject is definitively determined as one that cannot be crossed: words can no longer express reality, which is why Benn reaches for such extreme means. The seemingly indifferent perspective of the lyrical subjects contains a latent disgust at the world without a spiritual dimension. Holan, however, employs different means: an ornamental Baroque style, the use of phonic configuration and a refined vocabulary. Unlike Benn, who deliberately deaestheticizes the text (with minor exceptions), Vladimír Holan employs means that are perceived as traditionally aesthetic in poetry. Yet the effect is shocking in a similar manner.

In the work of Jiři Orten (1919-1941), the poet of tragic love, the motif of a drowned young woman appears repeatedly, which is not surprising. In the poem "Utonulá" (The Drowned One) from the collection Cítanka jaro (Reader of Spring) published in 1939, the motif had an emblematic form:

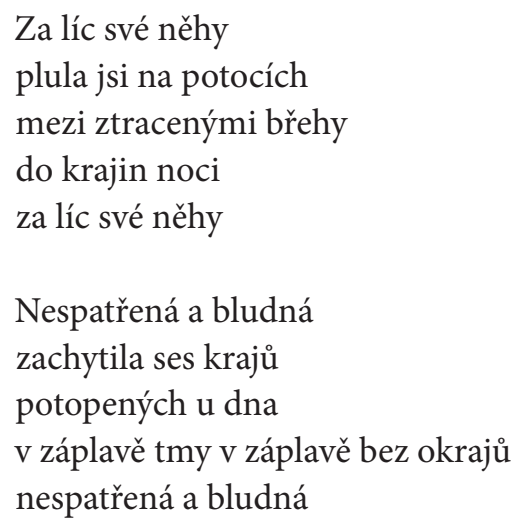

Milenky konci za zábradlím tam neznáme tam něhy líc je roztř́štěna tím co kradly ubohé vlny kráse smrtelnic

Ale ty prý ses dala jediným rozevřením klína vodníkům kterým bylo zima

Almužna lásky třeba malá ti ke smrti pomáhala (Orten 32) 
In English translation:

\author{
For the face of your warmth \\ you flew along every brook \\ between banks you have lost \\ to dark lands you mistook \\ for the face of your warmth \\ Unseen and troublesome \\ you've been grasping the ground \\ at the bottom with awesome \\ darkness floating around \\ unseen and troublesome \\ Lovers hide behind parapets \\ where unknown is the face of grace \\ smashed by \\ what \\ they took by stealth \\ from mortal beauty of poor waves
}

But one hears you gave it all

to shivering water-sprites

just by opening your thighs

Love's pittance even so small

assists you to bear death's toll (Orten, Selected Poems)

The drowned young woman floating on the flowing water definitely evokes Ophelia. Moreover, what is thematized here is not the process of drowning (as it would in a folk ballad for instance) but only its aestheticized result. Eroticism ("opening your thighs") combined with tragedy in the form of a prematurely ended life is more or less typical for Orten; however, what stands out here is the connection of these two aspects and the water element.

\title{
4. Conclusion
}

The Expressionist poems show that the role of Ophelia as the successor of the muse was only temporary and instrumental. It actually represents a sim- 
ilarly mysterious type of a figure as that of Trakl's sister or Rilke's angel: a deliberately built bridge to transcendence. Thus, Ophelia was destined to first lose her name and later become the object of irony, which is a certain reaction to Nietzschean nihilism. The development of this motif represents a very illustrative example of the disintegration of a world which could be described by words. The figure of Ophelia, or the drowned young woman in the space of Czech poetry by Petr Bezruč, Vladimír Holan and Jiří Orten equals the international renderings in its degree of expressivity.

\section{| References}

Primary Sources

Benn, Gottfried. "Beautiful Youth.” Trans. Michael Hofmann. Poetry Foundation, https://tinyurl.com/y9rhneeo. Accessed 4 November 2019.

---. Gesammelte Werke I. Gedichte I. Stuttgart: Klett-Cotta, 1989a.

---. Gesammelte Werke IV. Autobiographische und vermischte Schriften. Stuttgart: Klett-Cotta, 1989b.

Bezruč, Petr. "Marycka Magdonova." Waymarking. Trans. Ian Milner, https:// tinyurl.com/yc9mxv6g. Accessed 4 November 2019.

---. Slezské písnè. Opava: Slezské zemské muzeum, 2017.

Heym, Georg. Dichtungen und Schriften. Band 1: Lyrik. Hamburg und München: Verlag Heinrich Ellermann, 1964.

---. “Ophelia." Trans. Wolfgang Steinmann. BrinDin Press, http://www.brindinpress.com/pgvb6836.htm. Accessed 4 November 2019.

Holan, Vladimír. “But Never Doubt I Love." Trans. Josef Tomáš. Vladimír Holan, Yet There Is Music, https://tinyurl.com/ycuhxwen. Accessed 4 November 2019.

---. Lamento. Spisy 3. Prague: Paseka, 2000.

---. "Homecoming." Trans. Josef Tomáš and Katarina Tomas. Vladimír Holan, Narrative Poems, https://tinyurl.com/y7grk82n. Accessed 4 November 2019.

---. Na celé ticho. Spisy 4. Prague: Paseka, 2001.

---. Př́běhy. Spisy 7. Prague: Paseka, 2002.

---. Nokturnál. Spisy 8. Prague: Paseka, 2003.

Orten, Jiří. Knihy veršu․ Prague: Český spisovatel, 1995.

---. “The Drowned One.” Jiři Orten, Selected Poems, https://tinyurl.com/y8lmdzkq. Accessed 4 November 2019.

Rimbaud, Jean Arthur. Poésies-Une saison en enfer, Illuminations, Oeuvres diverses. Paris: Presses Pocket, 1981. 
---. “Ophelia.” Poetry Nook, https://www.poetrynook.com/poem/ophelia-o. Accessed 4 November 2019.

Shakespeare, William. Hamlet, Prince of Denmark / Hamlet, princ dánský. Prague: Romeo, 1999.

Trakl, Georg. Das dichterische Werk. München: Dtv, 1998.

---. “Wind, white voice ...” Werschs Literaturnische, https://tinyurl.com/yattrklo. Accessed 4 November 2019.

\section{SECONDARY Sources}

Bachelard, Gaston. Water and Dreams: An Essay on the Imagination of Matter. Trans. Edith R. Farrell. Dallas: Pegasus Foundation, Dallas Institute of Humanities and Culture, 1983.

Bayer, Frauke. Mythos Ophelia: Zur Literatur - und Bild-Geschichte einer Weiblichkeitsimagination zwischen Romantik und Gegenwart. Würzburg: Ergon Verlag, 2009.

Blažíček, Přemysl. Sebeuvědomění poezie (Nad básněmi V. Holana). Pardubice/ Prague: Akcent/Ústav pro českou a světovou literaturu AV ČR, 1991.

Blume, Bernhard. "Das ertrunkene Mädchen. Rimbauds Ophélie und die deutsche Literatur.” In Germanisch-Romanische Monatsschrift. Heidelberg: Universitätsverlag Winter 35 (1954): 108-119.

Bronfen, Elisabeth. Nur über ihre Leiche: Tod, Weiblichkeit und Ästhetik. Würzburg: Königshausen und Neumann, 2004.

Camden, Carroll. “On Ophelia’s Madness.” Shakespeare Quarterly_Folger Shakespeare Library 15.2 (1964): 247-255.

Galmiche, Xavier. Vladimír Holan, bibliotékář Boha (Praha 1905-1980). Prague: Akropolis, 2012.

Grimm, Reinhold. "Ein Wegbereiter." Strukturen. Essays zur deutschen Literatur. Göttingen: Sachse und Pohl, 1982. 124-145.

Grimm, Reinhold. “Georg Trakls Verhältnis zu Rimbaud.” Germanisch-Romanische Monatsschrift 9.2 (1959): 288-315.

Huyssen, Andreas. Miniature Metropolis: Literature in an Age of Photography and Film. Cambridge: Harvard University Press, 2015.

Kindler, Simone. Ophelia: Der Wandel von Frauenbild und Bildmotiv. Berlin: Reimer, 2004.

Křivánek, Vladimír. Vladimír Holan básník. Prague: Aleš Prstek, 2010.

Malý, Radek. Motiv utonulé dívky v poezii německého expresionismu. Svět literatury 54 (2016): 75-89.

Malý, Radek. “Tř́i podoby Ofélie v poezii Vladimíra Holana.” Česká literatura 4 (2018): 489-503.

Menschendörfer, Adolf. “Trakl und Rimbaud.” Klingsohr II 13.4 (1925): 93-99. 
Opelík, Jiř́i. Holanovské nápovědy. Prague: Thyrsus, 2004.

Owen, Ruth J. "Voicing the Drowned Girl: Poems by Hilde Domin, Ulla Hahn, Sarah Kirsch, and Barbara Köhler in the German Tradition of Representing Ophelia." The Modern Language Review 3.102 (2007): 781-792.

Phillips, David. "In Search of an Unknown Woman: L'Inconnue de la Seine." Neophilologus 66.4 (1982): 321-327.

Ripellino, Angelo Maria. “Úvod k Vladimíru Holanovi.” Host do domu 15.2 (1968) 31-37.

Saliot, Anne-Gaëlle. The Drowned Muse: Casting the Unknown Woman of the Seine Across the Tides of Modernity. New York: Oxford University Press, 2015.

Špirit, Michael. "Poezie a komentářVladimír Holan a jeho souputníci. Sborník příspěvků z III. kongresu světové literárněvědné bohemistiky, sv. 2. Ed. Vratislav Färber. Praha: Ústav pro českou literaturu AV ČR, 2006. 151-157.

Würffel, Stefan Bodo. Ophelia: Figur und Entfremdung. Bern: A. Francke, 1985.

\section{| Abstrakt}

RADEK MaLÝ

Figura Ofelii w poezji ekspresjonistycznej. Niemiecko-czeskie porównanie

Artykuł dotyczy interpretacji postaci Ofelii w czeskiej poezji współczesnej w porównaniu z poezją europejskiego ekspresjonizmu. Estetyka obrazu śmierci Ofelii $\mathrm{z}$ dramatu Hamlet Szekspira wpłynęła na literaturę tego okresu i ją zainspirowała. Wpływ ten wyraziście odzwierciedlił się w poezji ekspresjonizmu niemieckiego, szczególnie w twórczości Georga Heyma, Gottfrieda Benna i Georga Trakla. Czescy poeci, którzy prezentowali to zjawisko w duchu ekspresjonizmu, to Jan Skácel, Vladimír Holan i Jiří Orten. Studium rozpatruje tę twórczość z punktu widzenia kompleksu Ofelii zdefiniowanego przez Gastona Bachelarda.

Słowa kluczowe: Ofelia; tonąca piękność; ekspresjonizm czeski; ekspresjonizm niemiecki 


\section{| Abstract \\ Radek Malý \\ The Figure of Ophelia in Expressionist Poetry: German and Czech Comparison}

The study deals with the rendition of the figure of Ophelia in Czech modern poetry in comparison with the poetry of European Expressionism. The image of Ophelia's aesthetic death from Shakespeare's drama Hamlet has influenced and inspired a whole range of artworks. It strongly reverberated in German Expressionist poetry, especially that by Georg Heym, Gottfried Benn and Georg Trakl. The Czech poets who approached this topic in the spirit of Expressionism include Jan Skácel, Vladimír Holan and Jiří Orten. The study further addresses these works in the light of the Ophelia complex as defined by Bachelard.

Keywords: Ophelia; drowned beauty; Czech Expressionism;

German Expressionism

\section{| About the Author}

Radek Malý graduated from the Faculty of Arts at Palacký University Olomouc (MA 2001) and finished his doctoral studies there (PhD 2005). He was awarded the degree of associate professor in theory of literature in 2013. He works as associate professor at the Faculty of Social Sciences at Charles University in Prague and at the Faculty of Arts at Palacký University in Olomouc. He deals with Czech-German literary relations, translatology (with a focus on artistic translation of poetry), literary Expressionism and literature for children and young adults. He has edited and translated poetry anthologies featuring modern German and Austrian poets (e.g. Stefan George, Georg Trakl, Paul Celan, R.M. Rilke and others). Besides a number of expert studies, he has published books on Georg Trakl (Spásná trhlina, 2006), Paul Celan (Domovem v jazyce, 2012) and the collection of studies Príběhy básní a jejich překladi̊ (2014).

E-mail: radek.maly@fsv.cuni.cz 
